\title{
Multilevel analysis of resonant leadership and subordinate's work performance during COVID-19: a study of the indian software industry
}

\author{
Niharika Gaan ${ }^{1} \mathbb{D} \cdot$ Yuhyung Shin ${ }^{2}$
}

Accepted: 18 January 2022

(c) The Author(s), under exclusive licence to Springer Science+Business Media, LLC, part of Springer Nature 2022

\begin{abstract}
This study examined the multilevel model that explains how the interaction effect of resonant leadership and gender identity influences proposed outcomes through the mediating role of psychological capital. We performed a multilevel analysis by conducting an online survey using multisource data from the 104 team/project leaders and 527 team members of nine major Indian IT companies. The results demonstrated that psychological capital positively and significantly mediated the relationship between resonant leadership and work performance. The mediation role was stronger when androgynous identity attenuated the relationship between resonant leadership and psychological capital at a higher level. The study adds a unique lens to the literature of resonant leadership and proposes outcomes by validating it through the hierarchical linear modelling principle and efficient statistical procedures. This is the first study to empirically confirm the multilevel moderation mediation process wherein psychological capital mediates the relationship between resonant leadership and work performance, subject to the leader's androgynous identity level.
\end{abstract}

Keywords Hierarchical Linear Modelling · Resonant Leadership · Subordinates' Work Performance · Psychological Capital $\cdot$ Leader Gender Identity

\section{Introduction}

The outbreak of the coronavirus disease 2019 (COVID-19) pandemic has resulted in a paradigm shift in the working style and work performance of employees (Carnevale \& Hatak, 2020) as well as the leader-subordinate interaction in digital space (Hinojosa et al., 2020) because of the pressing need of techno-dexterity for the dispersed workforce. The majority of Indian information technology (IT) companies have resorted to rigorous employee performance metrics and massive retrenchment and pay cuts amid the pandemic (Mohapatra, 2020). Furthermore, since the pandemic, increased workload and working hours have caused considerable stress among software professionals (Russo

Niharika Gaan

niharika@mdim.ac.in

Yuhyung Shin

yuhyung@ hanyang.ac.kr

1 Human Resource and Organizational Behavior, MDI Murshidabad, Raghunathganj, West Bengal 742235, India

2 School of Business, Hanyang University, Seoul, Korea et al., 2021). Such an increased level of stress, coupled with anxiety and concerns regarding the COVID-19 pandemic, makes it crucial to effectively manage the psychological capital and well-being of the IT workforce. Thus, determining the type of leadership that helps boost the psychological capital and work performance of employees even in the pandemic is vital.

Previous studies on COVID-19 have generally identified task- or relationship-oriented leadership as a critical antecedent of employees' psychological capital and work performance. Some studies have suggested that in a pandemic situation, task-oriented leadership (e.g. decisive or safety leadership) is beneficial for managing the uncertainty, providing subordinates with clear directions, making timely and effective decisions, and resolving safety concerns and issues (Aquilia et al., 2020; Zhang et al., 2020). Other studies have highlighted the importance of relationship-oriented leadership (e.g. supportive or inclusive leadership) that empathises with and takes care of employees' stress amid the pandemic (Ahmed et al., 2020; Lazim et al., 2020; Zhao et al., 2020). Taking a step further from this line of research, we contend that resonant leadership, which involves a leader's emotional competence, is crucial for alleviating subordinates' 
psychological stress. Resonant leadership refers to the 'behaviour of leaders who demonstrate a high level of emotional intelligence, are in tune with the emotions of those around them, use empathy and manage their own emotions effectively to build strong, trusting relationships, and create a climate of optimism that inspires commitment (Squires et al., 2010)'. Although an increasing number of studies have emphasised the importance of psychological capital (i.e. hope, efficacy, resilience, and optimism) in coping with the COVID-19 crisis (Killgore et al., 2020; Kokubun et al., 2020; Prime et al., 2020), few studies have explored the role of resonant leadership in the context of the pandemic. Given that a leader's emotional intelligence and leadership are preconditions for building positive psychological capital among subordinates (Cummings, 2004; Hatfield et al., 1994), investigating the effect of resonant leadership in the context of the pandemic is pivotal. Furthermore, because a leader's emotional intelligence exerts a multilevel effect on work outcomes (Druskat et al., 2003), a team leader's resonant leadership might affect team members' psychological capital and resultant performance. Thus, the first objective of this study is to examine the cross-level relationship between the resonant leadership of a team leader and the psychological capital and work performance of team members in the IT industry.

This study explores the boundary condition that strengthens or weakens the effect of resonant leadership on employee outcomes. The leadership literature indicates that gender role identity influences the effectiveness of a specific form of leadership. Embry et al. (2008) reported that leaders who have role identities inconsistent with their gender are evaluated more positively, suggesting that displaying both masculine and feminine roles strengthens the positive effect of leadership. In particular, given that the effective utilisation of emotional intelligence requires both masculine (e.g. probing and recognising one's feelings) and feminine (e.g. understanding others' intentions, desires, and motivations) roles (Martínez-Marín et al., 2021), resonant leaders must exhibit both roles to lead their followers by using emotional intelligence effectively. Drawing on gender role theory (GRT) (Bem, 1975; Eagly \& Karau, 2002), we argue that the effect of resonant leadership will be more pronounced when a leader exhibits androgynous identity. According to the gender role perspective, masculinity represents being assertive, aggressive, competitive, decisive, and independent, whereas femininity is associated with being compassionate, sympathetic, and caring. Furthermore, this perspective asserts that an androgynous identity possessing masculine and feminine traits is more effective under a crisis (BlakeBeard et al., 2020). Based on this theory, we contend that a leader's androgynous identity offsets the weaknesses of resonant leadership (lack of task-oriented leadership) under a crisis and therefore strengthens its positive effect. Hence, the second objective of this study is to examine the moderating effect of a leader's androgynous identity on the relationship among resonant leadership, psychological capital, and work performance.

This study investigates three critical issues surrounding leadership processes that are crucial to the IT industry and may support them to tide over the crisis, thereby making a unique contribution to the existing leadership literature. First, the study aims at plugging the research gap by investigating the effect of resonant leadership on proposed outcomes in the context of the IT industry and COVID-19. Complementing previous studies on leadership in the context of the pandemic, this study presents resonant leadership as a new form of leadership that can help boost employees' psychological capital under challenging times. Second, this study determines the mediating path between resonant leadership and work performance. If employees' psychological capital is determined to be a substantial mediator linking resonant leadership and work performance, it can provide implications for managing employees' work performance amid the pandemic. Third, the IT industry has witnessed increasing gender diversity (Chakraborty \& Chatterjee, 2020) with the changing workforce landscape, thus calling for more gender-balanced managerial practices (Blake-Beard et al., 2020; Paustian-Underdahl et al., 2014). Examining the moderating effect of androgynous gender identity offers insights into the role of gender role identity in the IT industry during the COVID-19 pandemic.

\section{Resonant leadership}

Resonant leadership refers to a relational leadership style rooted in emotional intelligence and involves empathising and striving to balance out own and others' emotions to build harmony with each other (Squires et al., 2010). Vision, overall positive mood, compassion, and altruism define the construct of resonant leadership (Boyatzis \& McKee, 2005; May et al., 2004; Squires et al., 2010). Employees and their perceptions, intentions, and behaviours considerably resonate with firms' goals (Cummings, 2004; Wong et al., 2013) in the presence of resonant leaders due to a high sense of higher purpose. Such leaders inspire employees to ward off fear arising from job loss and fear in times of despair (Marques, 2015) and create a vibrant organisational climate by cultivating hope, mindfulness, and compassion (Goleman et al., 2002; Squires et al., 2010). They convert challenges into opportunities by being mindful of current business situations (Jacobs \& Blustein, 2008). Moreover, they demonstrate the ability to nurture and develop their followers and inspire them by showing a glimmer of hope, especially during the challenging times of crisis (Marques, 2015; Lenka \& Tiwari, 2019). The edifice of a resonant 
leader is built on the philosophy that is in sync with the dynamic nature of the IT industry (Lee, 2000) and occupation that needs continual change, renewal, growth, and development (Armstrong et al., 2007). Furthermore, the IT industry entails team or project-based tasks coupled with aggressive timelines (Messersmith, 2007) and fast-paced technological disruptions (Sagara \& Das, 2020). This, in turn, demands an effective persona within an IT leader who can completely leverage emotional intelligent communication (Sharma, 2012). Emotional intelligence can be observed in a resonant leader who aims to change through selfless attitude, care, concern, and well-being of self and others fundamentally rooted in Indian values (Fry, 2003). Congruent to such cultural expectations, a resonant leader demonstrates a blend of visionary, coaching, affinitive, and democratic approaches, suitable to a changing landscape wherein a fluid leadership style is much demanded (Laschinger et al., 2014, p. 7). Given such contextual relevance of resonant leaders and the concept being at the nascent stage (Lenka \& Tiwari, 2016), little is known regarding the applicability of resonant leadership in the IT sector, thus requiring additional studies on this topic. The importance of resonant leadership in the IT sector is posited to be more pronounced in the pandemic situation in which software professionals are experiencing a decrease in salaries and an increase in workload. Because their psychological distress becomes more severe during the pandemic, resonant leadership is necessary to help them cope with stressors arising from the pandemic and maintain their psychological capital.

\section{Relationship between Resonant leadership and Work Performance}

The use of relational-oriented behaviours can be advantageous in the context of COVID-19 (Hinojosa et al., 2020) for posing stronger identifications with a leader and leader effectiveness (Derue et al., 2011; Wagner et al., 2013). However, leadership effectiveness can be more effectively studied by examining its reciprocity wherein the work outcomes of subordinates play a vital role. The essence of studying software professionals' work performance is based on the fact that they have specialised and hard-to-replace skills, which increase the likelihood of earning a competitive advantage (McKnight et al., 2009) for a firm. Such skills are continually updated due to the nature of the occupation (Armstrong et al., 2007). Because software professionals work in a team and remote working poses challenges on the collaboration and communication front (Buffer 2020), it is more likely to affect their performance (Russo et al., 2021). Congruent with such expectations and demands in a crisis, resonant leaders with clearly defined priorities (such as reskilling and constant conversations) and a high tolerance for employee mistakes can motivate employees to accomplish desired business outcomes (Lenka \& Tiwari, 2016). The association is assumed to be positive and effective because resonant leadership contains transformational elements (Marques, 2015), and transformational elements are the strongest predictors of subordinates' performance (Avolio et al., 1999; Lowe et al., 1996). However, the linkage between resonant leadership and followers' outcomes lacks empirical support in the context of the relational distance created by a crisis where leader-subordinate interactions are digitally facilitated. The linkage between resonant leadership and subordinate outcomes in the health care sector has been pervasive (Wagner et al., 2013). Previous studies suffer from methodical lacunae in linking resonant leadership (rated by subordinates) with work outcomes (rated by a supervisor) (Bawafaa et al., 2015). However, the relationship between resonant leadership and work performance under extreme conditions wherein dispersed team members work in isolation and non-dedicated workspaces at home due to the COVID-19 pandemic remains to be established. Moreover, limited studies have investigated multilevel leadership processes and their effects on subordinates' outcomes in a crisis-ridden situation, with few exceptions in the service sector (Stoker et al., 2019; Bartsch et al., 2020). Considering the present crisis that has exerted a multilevel effect (van Esch et al., 2021), we hypothesised that resonant leadership would positively affect the work performance of software professionals during the pandemic.

H1: Resonant leadership is positively related to software professionals' work performance during the COVID-19 pandemic.

\section{Relationship between resonant leadership and psychological capital}

Psychological capital embodies individuals' psychological strength, perceptions, attitudes toward work, and general outlook on life (Luthans et al., 2008). According to the positive psychology literature, positive organisational behaviour aims to identify enablers that conform to positive behaviour. Seligman (2002) indicated that hope, optimism, resilience, and self-efficacy are the measurable dimensions of positive organisational behaviour that define the psychological capital construct. Based on positive psychology, these measurable dimensions of positive organisational behaviours, such as self-efficacy, play a substantial role in situations marked by uncertainty in job demands and the changing IT landscape (Sihag, 2020) due to crisis. A resonant leader is assumed to trigger such ability in subordinates to bounce back in adversity (Jacobs \& Blustein, 2008). Therefore, resonant 
leadership can be treated as a potential antecedent to followers' psychological capital (Bass, 1990; Gooty et al., 2009).

Software professionals may encounter competing demands owing to the nature of their occupation (Messersmith, 2007) and dynamic environment (Aggarwal \& Thite, 2003) that create challenges (work pressure, irritation, depression, and anxiety arising out of loneliness and remote working) to maintain emotional stability (Lee, 2000). Under such circumstances, a resonant leader is assumed to precede subordinates' psychological capital by fostering the culture underpinning the growth and development of employees' psychological resources. Such assumptions can be attributable to a couple of reasons. First, resonant leaders regulate their and others' emotions by fostering the emotional resilience of their employees. These leaders invoke positive emotions among subordinates by delving into their work-related issues and solving their problems at the workplace (Cummings, 2004). Such positive psychological resources can prevent their behaviours from exerting a detrimental effect on their work performance. Second, the components of resonant leadership, including vision, overall positive mood, and compassion (Boyatzis et al., 2013; Mahon et al., 2014), can inspire employees for viable business success, foster their contentment towards assigned work roles, and pardon their mistakes by being aware of employees' emotions and feelings. Third, resonant leaders can set goals and guide employees for achieving firms' mutual objectives (Cummings et al., 2010; Wong et al., 2013) by believing in the revival, growth, and development of subordinates.

H2: Resonant leadership is positively related to the psychological capital of software professionals during the COVID-19 pandemic.

\section{Relationship between psychological capital and work performance}

Psychological capital accounts for substantial variations in job performance (Luthans et al., 2008) and synergistically acts to improve employee attitudes, behaviours, and outcomes (Avey et al., 2011; Chiniara and Bentein 2016; Walumbwa et al., 2010). A meta-analysis reported that the four types of psychological capital have a positive relationship with employee performance (Avey et al., 2011). Psychological capital components, namely hope, self-efficacy, resilience, and optimism, motivate employees to exert sustained energy and resources in their core work activities, thereby leading to increased performance. In particular, the positive link between self-efficacy and work performance has been well established in the literature (Stajkovic \& Luthans, 1998). When employees believe that they can perform their tasks efficiently, they are likely to perform well.
Drawing from the findings of this meta-analysis, we propose a positive relationship between psychological capital and work performance among software professionals.

H3: The psychological capital of software professionals is positively related to their performance during the COVID-19 pandemic.

\section{Mediating role of psychological capital}

Based on the relationships mentioned above, psychological capital might mediate the relationship between resonant leadership and employee work performance. This relationship is supported by social exchange theory (SET) (Blau, 1964) and social learning theory (SLT) (Bandura, 1977). SET postulates that leaders and subordinates form an exchange relationship wherein they reciprocate with resources received from the other party. Leaders who exercise resonant leadership guide their subordinates with a high level of emotional intelligence. Because subordinates feel that the leader provides them with emotional resources necessary for coping with stressors, they reciprocate with positive psychological capital such as hope, optimism, resilience, and self-efficacy. Such positive resources enable subordinates to remain motivated and engaged at work, thus resulting in higher work performance.

According to SLT, subordinates tend to emulate a leader's effective behaviour. Subordinates working with resonant leaders are likely to model and learn the leader's emotional regulation capabilities. This enables them to be hopeful even in a crisis. Because subordinates can effectively regulate their emotions, they can better allocate their psychological resources to core task activities, which, in turn, can enhance their work performance. Accordingly, we propose the following hypothesis:

H4: The psychological capital of software professionals mediates the relationship between resonant leadership and their work performance during COVID-19.

\section{The moderating role of gender identity}

Studies have indicated how numerous demographic characteristics, such as age, gender, and ethnicity, can become catalysts for leadership effectiveness (e.g., McColl-Kennedy \& Anderson, 2005; Ahmad, 2008) and the perceived performance of subordinates (Eagly \& Karau, 2002; PaustianUnderdahl et al., 2014). Gender role identity is a crucial facet of the multilevel and multidimensional phenomenon of 'gender' (Ayman \& Korabik, 2010) that speaks of one's personal belief regarding psychological characteristics 
associated with gender (Bem, 1975). According to the gender role literature, leaders can exhibit behaviours incongruent with gender stereotypes. In other words, male leaders may exhibit feminine behaviours, whereas female leaders may exhibit masculine behaviours. Their choice of gendercongruent or gender-incongruent behaviours is dependent on the situation (Park, 1997). Thus, when both identities (androgyny) are exhibited regardless of gender, it can lead to favourable consequences (Cook, 1985). Numerous studies have been conducted based on their polarised identity and the tenets of GRT (Bem, 1975; Eagly \& Karau, 2002). However, androgynous gender identity that is situation-specific is an under-researched area. Both gender and gender role identity are not present simultaneously. Moreover, although previous studies have indicated that gender group identification has served as a moderator (Wilson \& Liu, 2003), its role in the leadership process is yet to be explored.

We argue that imminent environmental crises such as the COVID-19 pandemic call for an androgynous identity for leaders. Resonant leaders would go beyond the stereotyped gender identity (Stewart \& McDermott, 2004) owing to their fluid and neutral behaviour ((Laschinger et al., 2014, p. 7). Therefore, resonant leadership is assumed to be more suitable in the workplace that demands flexibility in leadership disposition (Wang et al., 2012), and androgyny can provide such flexibility (Kark et al., 2012). Furthermore, a study reported that context predicts the effectiveness of leadership style (Gartzia et al., 2012) and is potentially more relevant in the ongoing pandemic situation. Such assumptions can be attributable to a couple of reasons. On the one hand, agentic attributes (masculine identity) might be preferred by the resonant leader at the time of urgency to take immediate decisions and attain the goal by looking into looming concerns (Blake-Beard et al., 2020). On the other hand, such urgency arising out of a pandemic situation may activate communal (feminine) attributes (Gartzia et al., 2012) to be equivalently demonstrated so that employees get the feeling of being valued and cared for (Dutta \& Mishra, 2021). Moreover, because of the changing workforce demography with a higher influx of women professionals, the leader displaying both stereotypically agentic and communal attributes (androgynous) will be considered more appropriate for an organisation (Wang et al., 2012) and potentially more effective (Gartzia \& Van Engen, 2012). This implies that leaders should be flexible in their behaviour in a nonstereotypical manner based on variations in events. Thus, compared with stereotypical leaders (masculine or feminine gender identity), resonant leaders would more effectively tide over the crisis with enhanced performance (Wisecup et al., 2005). In other words, given the pandemic situation, a resonant leader would have a better opportunity to be evaluated positively by the subordinate if the leader makes an eclectic choice of both attributes. Therefore, their interaction would indirectly affect subordinate's performance (Zhang et al., 2020; ParentRocheleau et al., 2020) if the perceived effect on the subordinate's psychological resources is positive (Avey et al., 2011) and more pronounced. Accordingly, we propose the following hypothesis:

H5a: A leader's androgynous identity moderates the relationship between resonant leadership and employee psychological capital, such that this relationship is more pronounced when androgynous identity is high than when it is low.

$H 5 b$ : A leader's androgynous identity moderates the indirect effect of resonant leadership on employee work performance through psychological capital, such that this indirect effect is more pronounced when androgynous identity is high than when it is low.

The conceptual model presented in Fig. 1 shows the theoretical framework indicated in the preceding sections. This framework will be examined in subsequent sections by testing hypotheses $H 1$ to $H 5 b$. If the conceptual model is empirically tested, the findings can be applied to the IT industry to strengthen the relationship between resonant leadership and work performance of subordinates through psychological capital with the conditional buffering role of gender identity.

\section{Method}

\section{Sample and procedure}

To construct a sample representing the Indian IT sector, nine Indian IT companies were examined by an Indian research firm. Seven of them were indigenously based but globally located, spanning their services from digital, IT distribution, and consulting to business solutions. The remaining two companies were globally based foreign multinational companies providing a similar range of services. Employees who were diverse in terms of gender and job position (team member, team leader, project manager, and senior project manager) were invited to our research. Data collection was performed with the support of the HR managers of the nine companies contacted by the research firm. All the companies were progressive because an almost equal number of women and men at the team member and project manager level were reported to have volunteered in the present study. Data were gathered after the onset of the COVID-19 pandemic (from May to September 2020). Similar to the data collection procedure used by Walumbwa et al. (2010), we collected two-wave, multisource data from team leaders and members to reduce potential common method variance (Podsakoff et al., 2012). A web-based survey was conducted by inviting participants through email to access it through a 
Fig. 1 Research Model

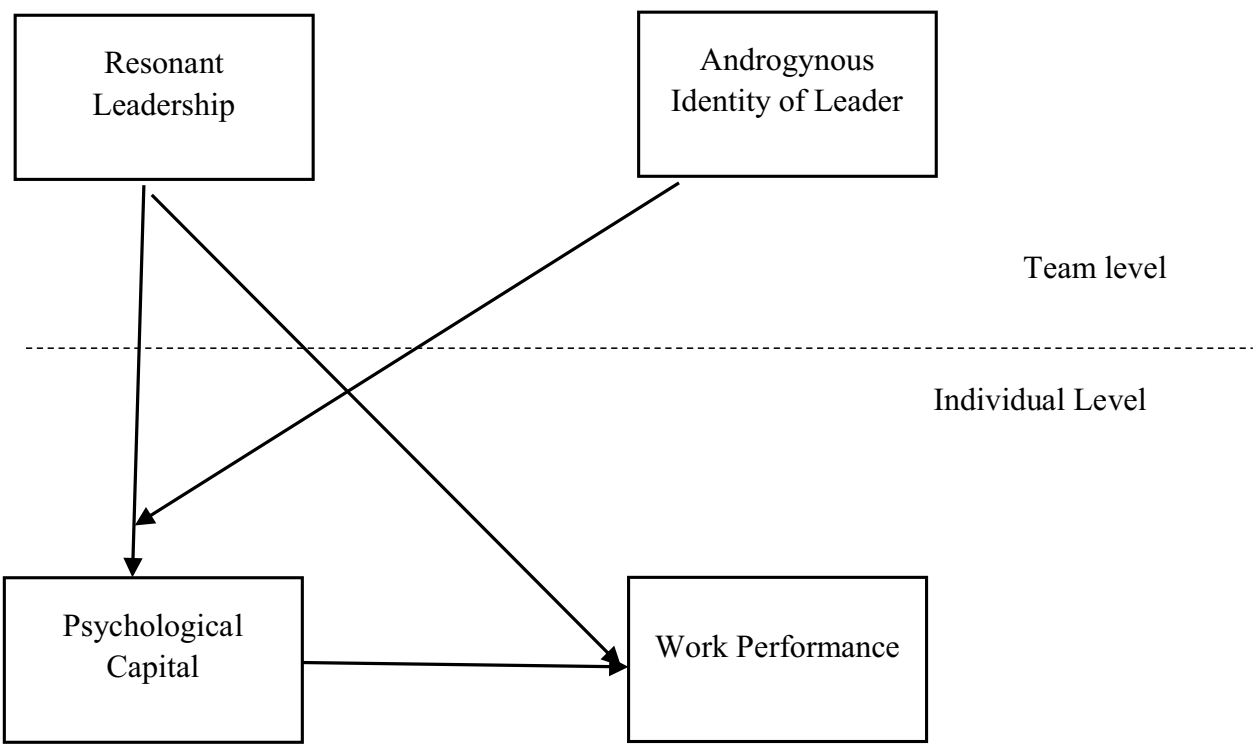

shared hyperlink. Participants were instructed to answer as honestly as possible to mitigate the speculation of receiving a socially desirable response. Assurance was provided to all respondents concerning data confidentiality and anonymity. The order of the items in the subordinate survey was counterbalanced for independent and dependent variables to reduce eventual response bias effects related to survey design. The online survey was administered 1 month apart in such a way that the first wave involved responses for the resonant leadership and gender identity of leaders rated by a subordinate. By contrast, the second wave involved responses from leaders rating their subordinates on their psychological capital and work performance. All such procedural measures followed the guideline provided by Podsakoff et al. (2003) to mitigate socially desirable bias considerably.

Of 674 team members and managers contacted, 104 leaders and 336 members from the team had a complete dataset of self and leader ratings. The remaining participants were screened out due to a single representation from the project team or registering an unfilled questionnaire. The paired response was identified through two anonymous security questions. To ensure that the participants were a good representation of their team members, we had at least five members of each participating team complete the online survey. As a result, the size of the participating teams ranged from 6 to 18. According to Aguinis et al. (2013), a minimum of 50 clusters are necessary for an unbiased estimation of a random effect in multilevel modelling. Maas and Hox (2005) recommended a sample size of 30-50 clusters and at least five individuals in each cluster. The level-2 $(N=104)$ and level-1 ( $\mathrm{N}=527)$ sample size exceeded this criterion, suggesting that our sample size was adequate for a multilevel analysis. This sample size is similar to prior multilevel studies (Chen et al., 2007). Data collection was performed between May and September 2020. The team size across the companies ranged from 6 to 18 . The average age of the total sample was approximately 33.2 years among the leaders (SD $=.45)$ and 27 years among the subordinates $(\mathrm{SD}=1.20)$; $52 \%$ were men and $48 \%$ were women. On average, respondents in the leader's category were associated with their company for 7 years $(\mathrm{SD}=.38)$, whereas respondents in the team member's category were associated with their company for 2 years $(\mathrm{SD}=.76)$. Respondents occupied different job positions: $50 \%$ were managers/professionals, whereas $50 \%$ were team members. Furthermore, $88.9 \%$ had a degree in electronics and telecommunications and computer science, and $11.1 \%$ possessed a postgraduate in computer science.

\section{Measures}

Resonant leadership This attribute was measured using Cummings et al.'s (2010) 10-item Resonant Leadership Scale that embodies four resonant leadership styles (selfawareness, social awareness, self-management, and relationship management) based on the Goleman's model of emotional intelligence. Sample items including 'My team leader focuses on success and potential rather than failures' and 'My team leader actively mentors and coaches individuals and teams' were rated by a subordinate. The scores ranged from 1 (strongly dissatisfied) to 5 (strongly satisfied). The Cronbach's $\alpha$ coefficient of the scale was .73.

Work performance Because the looming crisis requires subordinates to fulfil the task by investing a considerable amount of time and energy (Bartsch et al., 2020), work performance was assessed using a five-item established scale (Brown \& Leigh's, 1996) of work intensity. Sample items showing the leader version include 'When my subordinates 
Table 1 Means, Standard Deviations, Correlations

\begin{tabular}{|c|c|c|c|c|c|c|c|c|c|c|c|c|}
\hline S1. No & Variables & Mean & $\mathrm{SD}$ & 1 & 2 & 3 & 4 & 5 & 6 & 7 & 8 & 9 \\
\hline & Level 1 & & & & & & & & & & & \\
\hline 1. & Age (S) & 24.75 & 1.32 & 1 & & & & & & & & \\
\hline 2. & Gender (S) & 1.25 & 0.50 & 0.04 & 1 & & & & & & & \\
\hline 3. & Marital Status (S) & 1.11 & 0.29 & 0.11 & 0.05 & 1 & & & & & & \\
\hline 4. & Position Tenure (S) & 2.44 & 0.72 & 0.07 & $-0.04 *$ & 0.03 & 1 & & & & & \\
\hline 5. & Company Tenure (S) & 3.02 & 0.63 & 0.01 & 0.02 & 0.04 & -0.05 & 1 & & & & \\
\hline 6. & Education (S) & 1.11 & 0.28 & 0.06 & -0.01 & 0.02 & 0.01 & 0.01 & 1 & & & \\
\hline 7 & Psychological Capital & 4.08 & 0.34 & 0.08 & $-0.03 *$ & 0.02 & $0.07 *$ & 0.02 & 0.01 & 0.83 & & \\
\hline \multirow[t]{2}{*}{8.} & Work Performance & 4.16 & 0.46 & 0.03 & $0.07 *$ & 0.01 & 0.04 & 0.02 & 0.10 & $0.34^{* *}$ & 0.91 & \\
\hline & Level 2 & & & & & & & & & & & \\
\hline 9. & Age (L) & 33.0 & 2.71 & 1 & & & & & & & & \\
\hline 10. & Gender (L) & 1.25 & 0.50 & 0.02 & 1 & & & & & & & \\
\hline 11. & Marital Status (L) & 1.56 & 0.49 & 0.03 & -0.06 & 1 & & & & & & \\
\hline 12. & Position Tenure (L) & 3.06 & 0.39 & 0.04 & -.06 & -.03 & 1 & & & & & \\
\hline 13. & Company Tenure (L) & 2.05 & 0.79 & -0.03 & -.04 & .11 & -.01 & 1 & & & & \\
\hline 14. & Education (L) & 1.32 & 1.35 & 0.00 & 0.02 & 0.01 & 0.00 & 0.01 & 1 & & & \\
\hline 15. & Resonant Leadership & 3.90 & 0.36 & $0.05 *$ & 0.03 & -0.01 & $-0.14 *$ & 0.07 & $0.03 *$ & 0.73 & & \\
\hline 16. & Gender Identity & 3.60 & 0.37 & 0.03 & 0.02 & 0.11 & $-0.03 *$ & 0.03 & 0.02 & $0.14^{*}$ & 0.81 & \\
\hline 17. & Team Size & 5.03 & 0.59 & 0.00 & 0.00 & 0.00 & -0.01 & 0.00 & 0.01 & $-0.01 *$ & 0.00 & 1 \\
\hline
\end{tabular}

$\mathrm{n}=527$ for resonant leadership, and Leader gender identity, $\mathrm{n}=104$ for Psychological capital and Work Performance, $\mathrm{n}=$ Sample Size, $\mathrm{L}=$ Leader, $\mathrm{S}=$ Subordinate, Cronbach $\alpha$ score is presented diagonally in the right side of the table.

$* \mathrm{p}<.05, * * \mathrm{p}<.01$

work, they do so with intensity' and 'When they work, they exert to the fullest'. The scores range from 1 (strongly dissatisfied) to 5 (strongly satisfied). The Cronbach's $\alpha$ coefficient of the scale was .91 .

Psychological capital We used Lorenz et al.'s (2016) compound PsyCap Scale, consisting of 12 items assessing hope, self-efficacy, optimism, and resilience. The team leaders rated on a 6-point scale of agreement (e.g., 'My subordinate always looks confident and could deal efficiently with unexpected events'). The Cronbach's $\alpha$ coefficient of the scale was .83.

Leader androgynous identity Among 60 items scored on a 7-point scale developed by Bem Sex Role Inventory (Bem, 1975) ('never or almost never true' to 'always or almost always true'), 20 items were chosen that represented androgynous behaviour. The Cronbach's $\alpha$ coefficient for each one item was .81.

Control variables Coding of the demographic variables presented in Table 1 included the following ranges: gender (1 $=$ male, $2=$ female $)$, age $(1=0-25$ years, $2=26-40$ years, $3=41-55$ years, and $4=$ over 55 years), position tenure ( 1 $=0-11$ months, $2=1-3$ years, $3=4-7$ years, and $4=8$ or more years $)$, and company tenure $(1=0-11$ months, $2=$
$1-3$ years, $3=4-7$ years, and $4=8$ or more years). Gender and age were selected

as control variables since female employees (Lehoczky, 2013; Portuguez Castro and Zermeño in press) and older employees (McMurray et al., 2012) exhibited greater psychological capital than their male and younger counterparts, respectively. Position tenure and company tenure were used as controls because of their positive relationships with leadership competencies (Blayney \& Blotnicky, 2010; Bernerth et al., 2018) and work performance ( $\mathrm{Ng} \&$ Feldman, 2010). In addition, team size was controlled due to its negative effect on individual work performance (Mueller, 2012).

\section{Analytical Strategy}

Because the hierarchical data structure of 527 team members nested in 104 teams were involved, hierarchical linear modelling (HLM) was performed to test the hypotheses. Before hypothesis testing, we aggregated team members' scores for resonant leadership and androgynous gender identity. We examined the within-team agreement by calculating $r_{w g}$, values for these variables. The $r_{w g}$, values for resonant leadership and androgynous gender identity were .73 and .76 , respectively, exceeding the critical value of .70 (James, 
1982). In addition, the intraclass coefficients (ICCs) were calculated to evaluate the reliability of group means and between-team variance (James, 1982). The ICC (1) values of resonant leadership and leader gender identity were .15 and .13, respectively. Their ICC (2) values were .62 and .67, respectively. These statistics justify the aggregation of data and the use of multilevel modelling (Campion et al., 1993).

To determine the discriminant validity of our measures, we performed confirmatory factor analysis by using two team-level variables and two individual-level variables in AMOS 25.0 version. At the team level, the two-factor model fit the data significantly compared with the one-factor model $\left[\chi^{2}(120)=2.41, \mathrm{CFI}=.96, \mathrm{NFI}=.96, \mathrm{SRMR}=.05\right] . \mathrm{At}$ the individual level, the two-factor model showed better fit compared with the one factor model $\left[\chi^{2}(463)=4.59, \mathrm{CFI}\right.$ $=.93, \mathrm{NFI}=.93, \mathrm{SRMR}=.03]$, thus confirming the discriminant validity between two variables.

\section{HLM tests}

Table 1 lists the descriptive statistics, internal consistency reliabilities, and intercorrelations of all the study variables. The correlation between demographic variables of subordinates and focal variables are consistent with the past research (Avey, 2014; Jackson et al., 1989). Similarly, the results showing a correlation between demographic variables of leaders and focal variables are concurring with the past studies as well (Korac-Kakabadse \& Korac-Kakabadse, 1997; McAdams \& de St. Aubin, 1992).

To test our hypotheses, we first ensured the presence of significant variance in psychological capital and work performance between and within teams. It was a prerequisite condition to perform cross-level analysis through HLM. Thus, we first estimated a null model in which a team member's psychological capital and work performance was considered to be a linear function of three parameters: the grand mean of the population of an individual, the random effect due to an individual, and the random effect due to a team. The results of the null model indicated that $55 \%$ of the variance in a team member's psychological capital and $62 \%$ of the variance in work performance were explained by between-team variance. These results warrant the adoption of HLM in the analysis (Bliese, 2000).

We tested H1-H5 by using HLM 7. We grand-mean-centred the predictors at level 1 but controlled for the betweengroup variance by including the group mean of psychological capital and work performance and the interaction term with level 2 variables (Aguinis et al., 2013). Table 2 presents a series of models obtained from hierarchical linear modelling (HLM) analysis.

As per Model 6 shown in Table 2, the positive association observed between resonant leadership and subordinates' work performance $(\gamma=.05, \mathrm{p}<.01)$ supported H1. Model 1 included all control variables. After controlling demographic variables (age, gender, experience, position tenure, education and experience of leader and subordinates), Model 2 revealed a significant and positive association between resonant leadership and psychological capital $(\gamma=.08, \mathrm{p}<.01)$, thus confirming $\mathrm{H} 2$. In similar lines, Model 5 included all control variables. After controlling control variables, Model 7 revealed a positive association between psychological capital and subordinates' work performance $(\gamma=.09, \mathrm{p}<.01)$, thereby supporting $H 3$. As per Model 8 shown in Table 2, when psychological capital entered the regression equation, the relationship between resonant leadership and work performance became nonsignificant, suggesting full mediation $(\gamma=.07, \mathrm{p}<.05)$. The deviance change result confirmed a significant fit improvement in Model 8 $(\Delta \times 2(1)=7.78, \mathrm{p}<.01)$. To test the cross-level mediation and effect within the variances, the Monte Carlo Method (MCM), a form of parametric bootstrapping, was used to generate $95 \%$ confidence interval (CI) values for the average indirect effect of psychological capital by using 20,000 random draws from the estimated sampling distribution of estimates (Preacher et al., 2010). When psychological capital entered the regression equation, the relationship between resonant leadership and work performance became nonsignificant, suggesting full mediation. Furthermore, resonant leadership exerted a significant indirect effect on work performance through psychological capital (indirect effect $=.10, \mathrm{p}<.01,95 \% \mathrm{CI}=.01, .26)$.

Model 4 shows the cross-level interaction effect of the resonant leadership style and androgynous identity of a leader on psychological capital. The interaction term $(\gamma=.20, \mathrm{p}<.05)$ significantly predicted the psychological capital, thus supporting $H 5 a$. The results are plotted on a graph presented in Fig. 2. As predicted, the positive relationship between resonant leadership and psychological capital was more pronounced when the leader's androgynous identity was high than when it was low.

As per Model 9, the conditional interaction effect of resonant leadership and gender identity on work performance through psychological capital proved to be significant and positive (indirect effect $=.18,95 \% \mathrm{CI}=.05, .36$ ), thus supporting $H 5 b$. The deviance test result indicated a significant fit improvement in Model $9(\Delta \chi 2(1)=17.06, \mathrm{p}<.01)$. To test $H 5 b$, the MCM was used to generate $95 \% \mathrm{CI}$ values for the average indirect effects of psychological capital in the presence of gender role identity (androgynous) by using 20,000 random draws from the estimated sampling distribution of estimates (Selig \& Preacher, 2009). The indirect effect of resonant leadership and work performance through psychological capital was nonsignificant when the leader's androgynous identity was low than when it was high (low: indirect effect $=.01,95 \% \mathrm{CI}$ $=-.07,10$. However, this effect was significant for the high and moderate levels of androgynous identity (high: indirect effect $=.27,95 \% \mathrm{CI}=.15, .40$; moderate: indirect effect $=$ $.09,95 \% \mathrm{CI}=.01, .25)$. Taken together, these findings support $H 5 b$. 
Table 2 Results of Hierarchical Linear Modelling

\begin{tabular}{|c|c|c|c|c|c|c|c|c|c|}
\hline Variables & $\begin{array}{l}\text { Model 1: } \\
\text { Psycho- } \\
\text { logical } \\
\text { Capital }\end{array}$ & $\begin{array}{l}\text { Model 2: } \\
\text { Psychologi- } \\
\text { cal Capital }\end{array}$ & $\begin{array}{l}\text { Model 3: } \\
\text { psychologi- } \\
\text { cal Capital }\end{array}$ & $\begin{array}{l}\text { Model 4: } \\
\text { Psychologi- } \\
\text { cal Capital }\end{array}$ & $\begin{array}{l}\text { Model 5: } \\
\text { Work Perfor- } \\
\text { mance }\end{array}$ & $\begin{array}{l}\text { Model 6: } \\
\text { Work Perfor- } \\
\text { mance }\end{array}$ & $\begin{array}{l}\text { Model 7: } \\
\text { Work Perfor- } \\
\text { mance }\end{array}$ & $\begin{array}{l}\text { Model 8: } \\
\text { Work Perfor- } \\
\text { mance }\end{array}$ & $\begin{array}{l}\text { Model 9: } \\
\text { Work Per- } \\
\text { formance }\end{array}$ \\
\hline \multicolumn{10}{|l|}{ Level 1} \\
\hline Intercept & $4.08 * *$ & $4.08 * *$ & $4.05 * *$ & $4.05 * *$ & $4.03 * *$ & $4.03 * *$ & $4.03 * *$ & $4.03 * *$ & $4.02 * *$ \\
\hline \multicolumn{10}{|l|}{ Subordinate } \\
\hline Age & 0.06 & 0.06 & 0.03 & 0.02 & 0.05 & 0.01 & 0.00 & 0.00 & 0.00 \\
\hline Gender & $-0.01 *$ & $-0.01 *$ & 0.00 & 0.00 & $0.04 *$ & $0.04 *$ & 0.02 & 0.02 & 0.01 \\
\hline $\begin{array}{r}\text { Marital } \\
\text { Status }\end{array}$ & 0.03 & 0.03 & 0.03 & 0.03 & 0.03 & 0.03 & 0.03 & 0.03 & 0.03 \\
\hline $\begin{array}{l}\text { Position } \\
\text { Tenure }\end{array}$ & $0.05^{*}$ & $0.05 *$ & $0.03 *$ & $0.02 *$ & 0.02 & 0.02 & 0.02 & 0.02 & 0.02 \\
\hline $\begin{array}{c}\text { Company } \\
\text { Tenure }\end{array}$ & 0.01 & 0.01 & 0.01 & 0.01 & 0.01 & 0.01 & 0.01 & 0.01 & 0.01 \\
\hline Education & -0.02 & -0.02 & -0.02 & -0.02 & -0.02 & -0.02 & -0.02 & -0.02 & -0.02 \\
\hline $\begin{array}{l}\text { Psychologi- } \\
\text { cal Capital }\end{array}$ & & & & & & & $0.09 * *(.02)$ & $0.07 * *(.02)$ & $0.07 * *(.02)$ \\
\hline \multicolumn{10}{|l|}{ Level 2} \\
\hline \multicolumn{10}{|l|}{ Leader } \\
\hline Age & 0.03 & 0.03 & 0.03 & 0.03 & 0.01 & 0.01 & 0.01 & 0.01 & 0.01 \\
\hline Gender & 0.07 & 0.07 & 0.07 & 0.07 & 0.03 & 0.03 & 0.03 & 0.03 & 0.03 \\
\hline $\begin{array}{r}\text { Marital } \\
\text { Status }\end{array}$ & 0.03 & 0.03 & 0.03 & 0.03 & 0.02 & 0.02 & 0.02 & 0.02 & 0.02 \\
\hline $\begin{array}{l}\text { Position } \\
\text { Tenure }\end{array}$ & $-0.09 *$ & $-0.09 *$ & $-0.04 *$ & $-0.02 *$ & $-0.07 *$ & $-0.07 *$ & $-0.03 *$ & $-0.03 *$ & $-0.01 *$ \\
\hline $\begin{array}{l}\text { Company } \\
\text { Tenure }\end{array}$ & 0.01 & 0.01 & 0.01 & 0.01 & 0.01 & 0.01 & 0.01 & 0.01 & 0.01 \\
\hline Education & 0.02 & 0.02 & 0.02 & 0.02 & 0.04 & 0.04 & 0.04 & 0.04 & 0.04 \\
\hline Team Size & 0.00 & 0.00 & 0.00 & 0.00 & $-0.01 *$ & $-0.01 *$ & $-0.01 *$ & $-0.01 *$ & $-0.01 *$ \\
\hline $\begin{array}{l}\text { Resonant } \\
\text { Leadership }\end{array}$ & & $0.08 * *(.02)$ & $0.08 * *(.02)$ & $0.08 * *(.02)$ & & $0.05 * *(.03)$ & & $0.02(.03)$ & $0.02(.03)$ \\
\hline $\begin{array}{l}\text { Androgy- } \\
\text { nous } \\
\text { Identity }\end{array}$ & & & $0.13 *(.03)$ & $0.13 *(.03)$ & & & & & $0.10 *(.04)$ \\
\hline $\begin{array}{l}\text { Resonant } \\
\text { Leadership } \\
\times \text { Androg- } \\
\text { ynous } \\
\text { Identity }\end{array}$ & & & & $0.20 *(.01)$ & & & & & $0.18^{* *}(.02)$ \\
\hline $\begin{array}{l}-2 \text { log likeli- } \\
\text { hood }\end{array}$ & 426.67 & 423.48 & 419.36 & 413.02 & 412.98 & 411.95 & 406.60 & 398.82 & 381.76 \\
\hline $\begin{array}{r}\text { Deviance } \\
\text { Change }\end{array}$ & & $3.19 *$ & $4.12 *$ & $7.34 *$ & & $1.03 *$ & $5.35^{*}$ & $7.78^{*}$ & $17.06^{*}$ \\
\hline
\end{tabular}

Note. $* \mathrm{p}<.05, * * \mathrm{p}<.01$

\section{Discussion}

This study investigated the multilevel mediation effects of gender identity on the relationship between resonant leadership and subordinates' performance through psychological capital. While testing all the hypotheses, we found that the findings concurred well with all the hypothesised relationships.
The results revealed that a more significant demonstration of resonant leadership increased the work performance of subordinates, thereby concurring with the findings of previous studies (Cummings et al., 2010; Boyatzis et al., 2013; Boyatzis \& Yeganeh, 2012). In addition, the results indicated that the gamma estimate of psychological capital towards the proposed outcome was relatively less; however, it is consistent 
Fig. 2 Moderating Role of Leader Gender Identity

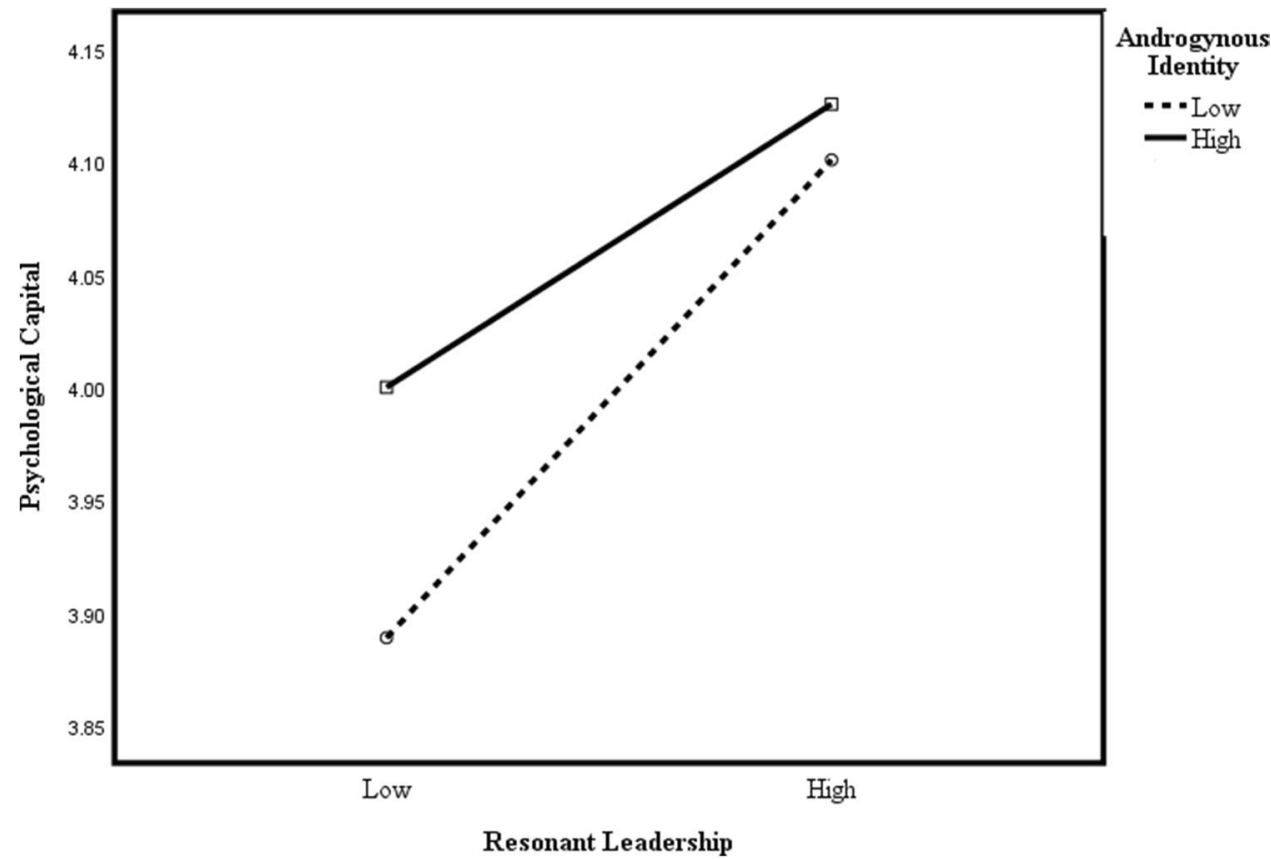

with the assumptions of previous studies (Boyatzis \& Soler, 2012). When the relationship between resonant leadership and psychological capital was moderated by the gender identity of the supervisor, the degree of prediction remarkably changed towards the proposed criterion variable, that is, psychological capital and work performance (Luthans et al., 2008). According to the literature (Park, 1997) and the findings presented in Fig. 2, the polarised form of leadership behaviour does not moderate the relationship between resonant leadership and subordinate performance as well as between psychological capital and subordinate performance. The plotted graph indicated that such neutral identity in resonant leadership is only effective towards psychological capital when it is displayed at a higher level. The results agree with the extant literature wherein embracing neutrality compared with polarised behaviour appears to be associated with effective leadership, thus exerting a positive effect on subordinates' performance (Blake-Beard et al., 2020). ${ }^{1}$

\section{Theoretical implications}

The findings on resonant leadership have several implications. First, by being the first study to set the contextual relevance of resonant leadership during COVID-19, this study contributes to the understanding of the role of resonant

\footnotetext{
1 To check the robustness of these findings, we ran all analyses with control variables excluded (Becker, 2005; Bernerth et al., 2018). The significance of the proposed relationships remained identical in the absence of control variables.
}

leadership in the context of the pandemic. This study indicated that the resonant leadership style resonates with subordinates and the organisation's long-term goal (McKee \& Massimilian, 2006) even in extreme conditions. Although studies have revealed a positive effect of resonant leadership on work outcomes such as job satisfaction, work engagement, and safety (Cummings et al., 2005; Squires et al., 2010; Wagner et al., 2013) during normal times, the present study revealed the relationship between resonant leadership and subordinates' work performance in the times of crisis. The positive relationship enforces the effectiveness of resonant leaders in digital platforms wherein virtual space can pose constraints in maintaining malleability in interactions, and such limitation may adversely affect their performance. By demonstrating that resonant leadership is crucial to the psychological capital and work performance of software professionals, this study highlights the cultural and practical relevance of resonant leadership in the Indian context wherein interpersonal relationships and self-less behaviour (Schwartz, 1977) play a vital role in making a leader competent in motivating and inspiring subordinates who are labelled as the knowledge workers of the IT industry.

The findings of our study indicate that the guaranteed effectiveness of psychological resources is subjected to the conditions of organisational intervention to bolster it (Luthans et al., 2008). In terms of the cultural relevance of a resonant leader, the renewal and growth of subordinates' psychological resources should be the major focus of the leader to increase the subordinates' security and emotional proximity in the leader-subordinate dyad (Hinojosa et al., 2020). The relationship between resonant leadership and 
employee psychological capital is affected by the leader's androgynous identity. The effectiveness of resonant leadership becomes more profound when the leader exhibits an androgynous identity. Because this effect held regardless of the leader's gender, both male and female leaders should display androgynous behaviours to make their leadership more effective. Because masculine and feminine behaviours offset the weaknesses of each other, possessing androgynous aspects is more effective in a crisis. By unveiling the interaction effect between resonant leadership and gender role identity in the context of the pandemic, our study provides nuanced understanding regarding the role of resonant leadership. This study opens the scope of future research wherein the gender of a resonant leader and its interaction with gender identity may be examined to discern the nuances of the gender and its effect on either side of the mediation path among resonant leadership, psychological capital, and work performance.

The present study theoretically contributes to the leadership literature by validating SET and SLT in the Indian IT sector. Our findings unequivocally confirmed that resonant leadership has a positive relationship with both employee psychological capital and work performance. As predicted by SET, resonant leadership is a form of a social exchange relationship between the leader and subordinates. Because subordinates receive positive emotional treatment from the leader, they tend to reciprocate it with positive psychological capital and desirable work performance. In addition, as postulated by SLT, resonant leadership can facilitate social learning processes among subordinates. By observing the emotional intelligence of resonant leaders, subordinates emulate and learn such effective emotion regulation skills, thereby displaying hope, self-efficacy, optimism, and resilience even in the face of the COVID-19 pandemic. Thus, by validating SET and SLT mechanisms underlying resonant leadership, this study enriches the theoretical understanding of resonant leadership.

\section{Practical implications}

Given that crisis management is the need of the hour in the COVID-19 context, the practising leader must handle it to ensure economic stability and expend efforts in building relational bonding with subordinates by adapting to the leadership style best suited to the situation (Hinojosa et al., 2020). Based on the present finding that resonant leadership is conducive to subordinates' psychological capital and work performance, we encourage IT organisations to foster resonant leadership among practising leaders. Cultivating leaders' emotional intelligence is vital to enhance their resonant leadership (Cummings et al., 2008). Therefore, IT organisations should train their leaders in leadership skills such as empathy, listening, and responding to subordinates' concerns (Laschinger et al., 2014). Leadership development programs can put major thrusts on topics such as vision, hope, compassion, and renewal, which are the major centripetal forces of resonant leadership. Such institutionalised and structured development-based programs can nurture leaders to inculcate the desired level of emotional intelligence that can be demonstrated in times of crisis. Moreover, practising leaders should receive regular feedback regarding their emotional intelligence and leadership behaviours (Laschinger et al., 2014) to enhance their self-awareness and continually develop their resonant leadership. Furthermore, IT leaders must explore virtual tools that can substitute proximity maintained in physical space because continuous interactions would uplift the psychological resources of software professionals to recoup in the unprecedented situation causing psychological distress (Hinojosa et al., 2020). Considering individual differences, they should devise an intervention mechanism to elevate the psychological resources of subordinates as a positive reinforcement to respond to pressure and perform (Lenka \& Tiwari, 2016). In addition, considering the beneficial effect of androgynous identity observed in the present study, we encourage IT organisations to implement diversity training that highlights the importance of gender role identity. Because inclusiveness and diversity have been the major focus and concerns in HR practices (Dutta Gupta et al., 2015), training programs geared towards the understanding of diversity and gender role identity can enable leaders to recognise the importance of androgynous identity and inculcate the eclectic choice of agentic and communal attributes (androgynous identity) to mitigate the negative consequences of the stereotyped evaluation of a leader.

\section{Limitation and future directions}

This study has some limitations that should be addressed. First, although this study used a two-wave design, the short interval between the two waves made it difficult to determine the causality among resonant leadership, psychological capital, and work performance. A longitudinal study incorporating a multilevel model should be performed in the future to understand the causal relationship of a predictor variable with a criterion variable (McCormick et al., 2020) by comparing between the first wave and second wave of COVID19. In addition, this study can investigate the effect of the predictor during post-COVID-19 to broaden the understanding regarding the contingency style of resonant leadership.

Second, the present nomological network examines subordinates' performance by measuring their work intensity; however, this method is limited by range restrictions (Bartsch et al., 2020) by confining to two activities such as long hours and hard work. Future studies may choose scales that contain no range restrictions to measure work 
performance and activities during the work period (Brown $\&$ Leigh, 1996). A meta-analysis can examine outcome variables such as job embeddedness, remote engagement, and occupational commitment by including cross-lagged studies with multiwave features to understand the sustained effect of resonant leadership.

Third, a leader-subordinate dyad representing non-IT jobs such as HR and finance can be considered in the IT industry itself along with IT jobs to investigate the effect of resonant leadership on subordinates' performance. It would be interesting to examine the effectiveness of resonant leadership in non-IT jobs that requires more human and emotional skills (such as HR and customer service). Furthermore, additional follow-up studies should be conducted to evaluate the effect of gender role identity on different jobs because different jobs require different levels of masculine and feminine behaviours. Future studies can fill the void by establishing the nuances of intersectionality between gender role identity and job type or characteristics.

Lastly, although the study reveals a positive effect of resonant leadership, the focus of the study precludes the comparison of different types of leadership. Because other studies have emphasised the importance of decisive leadership in the context of the pandemic, our findings cannot indicate whether resonant leadership is more effective than other types of leadership in the context of the pandemic. Future researchers should answer this question by examining the effectiveness of different types of leadership (Siangchokyoo et al., 2020), especially in a crisis-ridden situation. Therefore, future studies can plug the void by overcoming the limitations mentioned above.

\section{Conclusion}

With the outbreak of COVID-19 and the enforcement of remote work practices, virtual interactions by the IT leader have become essential to support software professionals to overcome all types of distress (Russo et al., 2021). Complementing the extant literature, the study could establish the contextual relevance of resonant leadership (Ahmed et al., 2020; Lazim et al., 2020; Zhao et al., 2020. Based on GRT (Bem, 1975; Eagly \& Karau, 2002), we developed a hypothesis model linking the interaction effect of resonant leadership and gender identity on work performance through the mediating effect of the psychological capital of software professionals. The model has shed light on the effectiveness of androgynous identity in buffering the relationship between resonant leadership and psychological capital. Leaders' androgynous identity can bolster the psychological capital of software professionals, thus improving their work performance in crises such as the current COVID-19 pandemic. The role of androgynous identity has provided a fresh perspective in the present study. If resonant leaders adopt such identity, they will create an inclusive culture that balances out the setbacks of the polarised role of identity, which lacks task orientation and more likely encourages negative repercussions.

Availability of data and material The datasets generated during and/ or analysed during the current study are not publicly available due to the non-disclosure bond signed by the corresponding author with the Research firm.

\section{Declaration}

Conflict of interest statement On behalf of all authors, the corresponding author states that there is no conflict of interest.

Ethical approval All procedures performed in studies involving human participants were in accordance with the ethical standards of the institutional and/or national research committee and with the 1964 Helsinki declaration and its later amendments or comparable ethical standards.

Informed consent Informed consent was obtained from all individual participants included in the study.

\section{References}

Aggarwal, N. M., \& Thite, M. (2003). Human resource issues, challenges and strategies in the Indian software industry. International Journal of Human Resources Development and Management, 3(3), 249-264. https://doi.org/10.1504/IJHRDM.2003. 003664

Aguinis, H., Gottfredson, R. K., \& Culpepper, S. A. (2013). Best-Practice Recommendations for Estimating Cross-Level Interaction Effects Using Multilevel Modelling. Journal of Management, 39(6), 1490-1528. doi: 10.1177\%2F0149206313478188

Ahmad, K. Z. B. (2008). Relationship between leader-subordinate personality congruence and performance \& satisfaction in the UK. Leadership \& Organizational Development Journal, 29, 396-411. https://doi.org/10.1108/01437730810887012

Ahmed, F., Zhao, F., \& Faraz, N. A. (2020). How and when does inclusive leadership curb psychological distress during a crisis? Evidence from the COVID-19 outbreak. Frontiers in Psychology, 11(1898), 1-13. https://doi.org/10.3389/fpsyg.2020. 01898

Armstrong, D. J., Riemenschneider, C. K., Allen, M. J., \& Reid, M. F. (2007). Advancement, voluntary turnover and women in IT: a cognitive study of work-family conflict. Information \& Management, 44, 142-153. https://doi.org/10.1016/j.im.2006.11.005

Avey, J.B., Reichard, R.J., Luthans, F., \& Mhatre, K.H. (2011). MetaAnalysis of the Impact of Positive Psychological Capital on Employee Attitudes, Behaviors, and Performance. Human Resource Development Quarterly, 22(2), 127-152. https://psycnet.apa.org/doi/10.1002/hrdq. 20070

Avey, J. B. (2014). The Left Side of Psychological Capital: New Evidence on the Antecedents of PsyCap. Journal of Leadership \& Organizational Studies., 21(2), 141-149. https://doi.org/10.1177/ 1548051813515516 
Avolio, B. J., Howell, J. M., \& Sosik, J. J. (1999). A funny thing happened on the way to the bottom line: humor as a moderator of leadership style effects. Academy of Management Journal, 42, 219-227. https://doi.org/10.2307/257094

Aquilia, A., Grimley, K., Jacobs, B., Kosturko, M., Mansfield, J., Mathers, C., Parniawski, P., Wood, L., \& Niederhauser, V. (2020). Nursing leadership during COVID-19: Enhancing patient, family and workforce experience. Patient Experience Journal, 7, 136-143. doi: 10.35680/2372-0247.1482

Ayman, R., \& Korabik, K. (2010). Leadership: Why gender \& culture matter. American Psychologist, 65(3), 157-170. https://doi.org/ 10.1037/a0018806

Bandura, A. (1977). Self-efficacy: Toward a unifying theory of behavioral change. Psychological Review, 84(2), 191-215. https://doi. org/10.1037/0033-295X.84.2.191

Bartsch, S., Weber, E., Büttgen, M., \& Huber, A. (2020). Leadership matters in crisis-induced digital transformation: how to lead service employees effectively during the COVID-19 pandemic. Journal of Service Management, 32(1), 71-85. https://doi.org/ 10.1108/JOSM-05-2020-0160

Bass, B. M. (1990). Handbook of leadership (3rd ed.). Free Press.

Bawafaa, E., Wong, C. A., \& Laschinger, H. (2015). The influence of resonant leadership on the structural empowerment and job satisfaction of registered nurses. Journal of Research in Nursing, 20(7), 610-622. https://doi.org/10.1177/1744987115603441

Becker, T. E. (2005). Potential problems in the statistical control of variables in organizational research: A qualitative analysis with recommendations. Organizational Research Methods, 8, 274289. https://doi.org/10.1177/1094428105278021

Bem, S. L. (1975). Sex role adaptability: One consequence of psychological androgyny. Journal of Personality \& Social Psychology, 31(4), 634-643. https://doi.org/10.1037/h0077098/

Bernerth, J. B., Cole, M. S., Taylor, E. C., \& Walker, H. J. (2018). Control Variables in Leadership Research: A Qualitative and Quantitative Review. Journal of Management, 44(1), 131-160. https://doi.org/10.1177/0149206317690586

Blake-Beard, S., Shapiro, M., \& Ingols, C. (2020). Feminine? Masculine? Androgynous leadership as a necessity in COVID-19. Gender in Management, 35(7/8), 607-617. https://doi.org/10. 1108/GM-07-2020-0222

Blayney, C., \& Blotnicky, K. (2010). The impact of gender on career paths and management capability in the Hotel Industry in Canada. Journal of Human Resources in Hospitality and Tourism, 9(3), 233-255. https://doi.org/10.1080/15332845.2010.487014

Blau, P. (1964). Justice in social exchange. Sociological Inquiry, 34, 193-246. https://doi.org/10.1111/j.1475-682X.1964.tb00583.x

Bliese, P.D. (2000). Within-group agreement, non-independence, and reliability: implications for data aggregation \& analysis. In K.J. Klein, \& S.W. Kozlowski, (eds., pp. 349-381), Multilevel Theory, Research, \& Methods in Organizations: Foundations, Extensions \& New Directions. San Francisco, CA: Jossey-Bass.

Boyatzis, R., \& McKee. A. (2005). Resonant Leadership. Boston, Massachussetts: Harvard Business School Press.

Boyatzis, R.E., \& Yeganeh, B. (2012). Mindfulness. Leadership Excellence, 29(3), 4. Retrieved May 15, 2021, from www.karolwasyl yshyn.com/pdf/LE0312-preview.pdf

Boyatzis, R. E., \& Soler, C. (2012). Vision, leadership and emotional intelligence transforming family business. Journal of Family Business Management, 2(1), 23-30. https://doi.org/10.1108/ 20436231211216394

Boyatzis, R. E., Smith, M. L., Van Oosten, E., \& Woolford, L. (2013). Developing resonant leaders through emotional intelligence, vision \& coaching. Organizational Dynamics, 42(1), 17-24. https://doi.org/10.1016/j.orgdyn.2012.12.003
Brown, S. P., \& Leigh, T. W. (1996). A new look at psychological climate and its relationship to job involvement, effort, and performance. Journal of Applied Psychology, 81(4), 358-368. https:// doi.org/10.1037/0022-3514.84.4.822

Carnevale, J. B., \& Hatak, I. (2020). Employee adjustment and wellbeing in the era of COVID-19: implications for human resource management. Journal of Business Research, 116, 183-187. https://doi.org/10.1097/nnr.0b013e3181ed74d5

Campion, M. A., Medsker, G. J., \& Higgs, A. C. (1993). Relations between work group characteristics and effectiveness: Implications for designing effective work groups. Personnel Psychology, 46, 823-850. https://doi.org/10.1111/j.1744-6570.1993. tb01571.x

Chakraborty, S., \& Chatterjee, L. (2020). Rationales of gender diversity management policies and practices in India: an exploratory empirical study in the Indian IT/ITeS industry. Equality, Diversity, \& Inclusion: International Journal, 39(6), 667-688. https:// doi.org/10.1108/EDI-04-2019-0124

Chen, G., Kirkman, B. L., Kanfer, R., Allen, D., \& Rosen, B. (2007). A multilevel study of leadership, empowerment, and performance in teams. Journal of Applied Psychology, 92, 331-346. https:// doi.org/10.1037/0021-9010.92.2.331

Cook, E. P. (1985). Psychological Androgyny. Pergamon Press.

Cummings, G. (2004). Investing relational energy: the hallmark of resonant leadership. Nursing Leadership, 17 (4), 76-87. doi: 10.12927/cjnl.2004.17019

Cummings, G. G., Hayduk, L., \& Estabrooks, C. A. (2005). Mitigating the impact of hospital restructuring on nurses: The responsibility of emotionally intelligent leadership. Nursing Research, 54(1), 2-12. https://doi.org/10.1097/00006199-200501000-00002

Cummings, G., Lee, H., \& Macgregor, T. (2008). Factors contributing to nursing leadership: A systematic review. Journal of Health Services Research \& Policy, 13(4), 240-248. https://doi.org/10. 1258/jhsrp.2008.007154

Cummings, G. G., Midodzi, W., Wong, C. A., \& Estabrooks, C. (2010). The contribution of hospital nursing leadership styles to 30-day patient mortality. Nursing Research, 59(5), 331-339. https://doi. org/10.1097/NNR.0b013e3181ed74d5

Derue, D., Nahrgang, J., Wellman, N., \& Humphrey, S. (2011). Trait and Behavioral Theories of Leadership: An integration and MetaAnalytic Test of Their Relative Validity. Personnel Psychology, 64, 7-52. https://doi.org/10.1111/j.1744-6570.2010.01201.x

Druskat, V. U., Wolff, S. B., Koman, E. C.S., \& Messer, T.E. (2003). Emotionally competent group norms and group effectiveness. Paper presented at the Annual Academy of Management Conference, Seattle, Wa.

Dutta, D., \& Mishra, S.K. (2021). Are women from Venus? A mixed-method study determining important predictors of job pursuit intention across gender groups. Equality, Diversity \& Inclusion. Advance online publication. doi: 10.1108/ EDI-03-2020-0059

Dutta Gupta, S., Raychaudhuri, A., \& Haldar, S. K. (2015). Information technology sector in India \& gender inclusivity. Gender in Management, 30(2), 94-108. https://doi.org/10.1108/ GM-04-2013-0046

Eagly, A. H., \& Karau, S. J. (2002). Role congruity theory of prejudice toward female leaders. Psychological Review, 109(3), 573-598. https://doi.org/10.1037/0033-295X.109.3.573

Embry, A., Padgett, M. Y., \& Caldwell, C. B. (2008). Can leaders step outside of the gender box? An examination of leadership and gender role stereotypes. Journal of Leadership \& Organizational Studies, 15(1), 30-45. doi: 10.1177\%2F1548051808318412

Fry, L. W. (2003). Toward a theory of spiritual leadership. The Leadership Quarterly, 14(6), 693-727. https://doi.org/10.1016/j.leaqua. 2003.09.001 
Gartzia, L., Ryan, M., Balluerka, N., \& Aritzeta, A. (2012). Think crisis-think female: Further evidence. European Journal of Work and Organizational Psychology, 21, 603-628. https://doi.org/10. 1080/1359432X.2011.591572

Gartzia, L., \& Van Engen, M. (2012). Are (male) leaders "feminine" enough?: Gendered traits of identity as mediators of sex differences in leadership styles. Gender in Management: An International Journal, 27, 296-314. https://doi.org/10.1108/17542 411211252624

Goleman, D., Boyatzis, R., \& McKee, A. (2002). The emotional reality of teams. Journal of Organizational Excellence, 21(2), 55-65. https://doi.org/10.1002/npr.10020

Gooty, J., Gavin, M., Johnson, P., Frazier, M., \& Snow, D. (2009). In the Eyes of the Beholder: Transformational Leadership, Positive Psychological Capital, and Performance. Journal of Leadership \& Organizational Studies, 15(4), 353-367. https://doi.org/10. $1177 / 1548051809332021$

Hatfield, E., Cacioppo, J. T., \& Rapson, R. L. (1994). Emotional contagion. Cambridge University Press.

Hinojosa, A. S., Shaine, M. J. D., \& McCauley, K. D. (2020). A strange situation indeed: Fostering leader-follower attachment security during unprecedented crisis. Management Decision, 58(10), 2099-2115. https://doi.org/10.1108/MD-08-2020-1142

James, L. R. (1982). Aggregation bias in estimates of perceptual agreement. Journal of Applied Psychology, 67(2), 219-229. https:// doi.org/10.1037/0021-9010.67.2.219

Jackson, S. E., Schuler, R. S., \& Rivero, J. C. (1989). Organizational characteristics as predictors of personnel practices. Personnel Psychology, 42, 727-786. https://doi.org/10.1111/j.1744-6570. 1989.tb00674.x

Jacobs, S. J., \& Blustein, D. L. (2008). Mindfulness as a coping mechanism for employment uncertainty. The Career Development Quarterly, 57(2), 174-180. https://doi.org/10.1109/EMR.2010. 5645752

Kark, R., Waismel-Manor, R., \& Shamir, B. (2012). Does valuing androgyny and femininity lead to a female advantage? The relationship between gender-role, transformational leadership and identification. The Leadership Quarterly, 23(3), 620-640. https:// doi.org/10.1016/j.leaqua.2011.12.012

Killgore, W. D. S., Taylor, E. C., Cloonan, S. A., \& Dailey, N. S. (2020). Psychological resilience during the COVID-19 lockdown. Psychiatry Research, 291, 1-2. https://doi.org/10.1016/j. psychres.2020.113216

Kokubun, K., Ino, Y., \& Ishimura, K. (2020). Social capital and resilience make an employee cooperate for coronavirus measures and lower his/her turnover intention. Retrieved July 5, 2021, from https://arxiv.org/abs/2007.07963

Korac-Kakabadse, A., \& Korac-Kakabadse, N. (1997). Best practice in the Australian Public Service (APS): an examination of discretionary leadership. Journal of Managerial Psychology, 12(7), 433-491. https://doi.org/10.1108/02683949710181209

Laschinger, H. S., Wong, C. A., Cummings, G. G., \& Grau, A. L. (2014). Resonant leadership \& workplace empowerment: the value of positive organizational cultures in reducing workplace incivility. Nursing Economics, 32(1), 5-44.

Lazim, N. L., Salim, N. A. M., \& Wahab, S. (2020). Low mortality among employee due to pandemic COVID-19 and leadership challenge: A literature survey. Asian Journal of Behavioral Sciences, 2(4), 26-32. http://myjms.mohe.gov.my/index.php/ ajbs

Lee, P. C. B. (2000). Turnover of information technology professionals: a contextual model. Accounting Management and Information Technologies, 10(2), 101-124. https://doi.org/10.1016/S09598022(99)00016-8
Lehoczky, M. H. (2013). The socio-demographic correlations. European Scientific Journal, 9(29), 1857. doi: 10.19044/esj.2013. v9n29p\%25p

Lenka, U., \& Tiwari, B. (2016). Achieving triple bottom line through resonant leadership: An Indian perspective. International Journal of Productivity \& Performance Management, 65(5), 694703. https://doi.org/10.1108/IJPPM-02-2015-0023

Lenka, U., \& Tiwari, B. (2019). Employee engagement: A study of survivors in Indian IT/ITES sector. IIMB Management Review, 32(3), 249-266. https://doi.org/10.1016/j.iimb.2019.10.003

Lowe, K. B., Kroeck, K. G., \& Sivasubramaniam, N. (1996). Effectiveness correlates of transformation and transactional leadership: A meta-analytic review of the MLQ literature. Leadership Quarterly, 7, 385-425. https://doi.org/10.1016/S1048-9843(96) 90027-2

Lorenz, T., Beer, C., Pütz, J., \& Heinitz, K. (2016). Measuring Psychological Capital: Construction and Validation of the Compound PsyCap Scale (CPC-12). PLoS ONE, 11(4), 15-28. https://doi. org/10.1371/journal.pone.0152892

Luthans, F., Avey, J. B., \& Patera, J. L. (2008). Experimental analysis of a web-based training intervention to develop positive psychological capital. Academy of Management Learning \& Education, 7(2), 209-221. https://doi.org/10.5465/AMLE.2008.32712618

Mahon, E. G., Taylor, S. N., \& Boyatzis, R. E. (2014). Antecedents of organizational engagement: exploring vision, mood \& perceived organizational support with emotional intelligence as a moderator. Frontiers in Psychology, 5, 11-22. https://doi.org/10.3389/ fpsyg.2014.01322

Marques, J. (2015). The changed leadership landscape: what matters today. Journal of Management Development, 34(10), 1310-1322. https://doi.org/10.1108/JMD-02-2015-0010

Martínez-Marín, M. D., Martínez, C., \& Paterna, C. (2021). Gendered self-concept and gender as predictors of emotional intelligence: A comparison through of age. Current Psychology, 40(4), 42054218. https://doi.org/10.1007/s12144-020-00904-z

Maas, C. J. M., \& Hox, J. J. (2005). Sufficient sample sizes for multilevel modeling. Methodology. European Journal of Research Methods for the Behavioral and Social Sciences, 1(3), 86-92. https://doi.org/10.1027/1614-2241.1.3.86

May, D. R., Gilson, R. L., \& Harter, L. M. (2004). The psychological conditions of meaningfulness, safety and availability \& the engagement of the human spirit at work. Journal of occupational \& organizational psychology, 77(1), 11-37. https://doi.org/10. 1348/096317904322915892

McAdams, D. P., \& de St. Aubin, E. (1992). A theory of generativity and its assessment through self-report, behavioral acts, and narrative themes in autobiography. Journal of Personality and Social Psychology, 62(3), 1003-1015. https://doi.org/10.1037/ 0022-3514.62.6.1003

McColl-Kennedy, J. R., \& Anderson, R. D. (2005). Subordinate-manager gender combination \& perceived leadership style influence on emotions, self-esteem \& organizational commitment. Journal of Business Research, 58, 115-125. https://doi.org/10.1016/ S0148-2963(03)00112-7

McCormick, B. W., Reeves, C. J., Downes, P. E., Li, N., \& Ilies, R. (2020). Scientific contributions of within-person research in management: Making the juice worth the squeeze. Journal of Management, 46(2), 321-350. doi: 10.1177/ 0149206318788435

McKee, A., \& Massimilian, D. (2006). Resonant leadership: A new kind of leadership for the digital age. Journal of Business Strategy, 27, 45-49. https://doi.org/10.1108/02756660610692707

McKnight, D. H., Philips, B., \& Hardgrave, B. C. (2009). Which reduces IT turnover intention the most: workplace characteristics or job characteristics? Information and Management, 46(3), 167-174. https://doi.org/10.1016/j.im.2009.01.002 
McMurray, A. J., Islam, M., Sarros, J. C., \& Pirola-Merlo, A. (2012). The impact of leadership on workgroup climate and performance in a non-profit organization. Leadership \& Organization Development Journal, 33(6), 522-549. https://doi.org/10.1108/01437 731211253000

Messersmith, J. (2007). Managing work-life conflict among information technology workers. Human Resource Management, 46(3), 429-451. https://doi.org/10.1002/hrm.20172

Mohapatra, D. (2020). Covid-19 impact: 10,000 IT professionals may have lost jobs in Q1. Retrieved July 1, 21, from https://www. business-standard.com/article/companies/covid-19-impact-10000-it-professionals-may-have-lost-jobs-in-q1-120070500938_1. html

Mueller, J. S. (2012). Why individuals in larger teams perform worse. Organizational Behavior and Human Decision Processes, 117, 111-124. https://doi.org/10.1016/j.obhdp.2011.08.004

Ng, T. W. H., \& Feldman, D. C. (2010). The Relationships of age with job attitudes: A meta-analysis. Personnel Psychology, 63(3), 677-718. https://doi.org/10.1111/j.1744-6570.2010.01184.x

Parent-Rocheleau, X., Bentein, K., \& Simard, G. (2020). Positive together? The effects of leader-follower (dis)similarity in psychological capital. Journal of Business Research, 110, 435-444. https://doi.org/10.1016/j.jbusres.2020.02.016

Park, D. (1997). Androgynous leadership style: an integration rather than a polarization. Leadership \& Organization Development Journal, 18(3), 166-171. https://doi.org/10.1108/0143773971 0168643

Paustian-Underdahl, S. C., Walker, L. S., \& Woehr, D. J. (2014). Gender and Perceptions of Leadership Effectiveness: A Meta-Analysis of Contextual Moderators. Journal of Applied Psychology, 99, 1129-1145. https://doi.org/10.1037/a0036751

Podsakoff, P., MacKenzie, S., Lee, J., \& Podsakoff, N. (2003). Common method biases in behavioral research: a critical review of the literature and recommended remedies. Journal of Applied Psychology, 88(5), 879-903. https://doi.org/10.1037/00219010.88.5.879

Podsakoff, P. M., MacKenzie, S. B., \& Podsakoff, N. P. (2012). Sources of method bias in social science research \& recommendations on how to control it. Annual Review of Psychology, 63, 539-569. https://doi.org/10.1146/annurev-psych-120710-100452

Portuguez Castro, M., \& Gómez Zermeño, M. G. (2020). Being an entrepreneur post-COVID-19-resilience in times of crisis: a systematic literature review. Journal of Entrepreneurship in Emerging Economies, In press. https://doi.org/10.1108/ JEEE-07-2020-0246

Preacher, K. J., Zyphur, M. J., \& Zhang, Z. (2010). A general multilevel SEM framework for assessing multilevel mediation. Psychological Methods, 15(3), 209-233. https://doi.org/10.1037/a0020141

Prime, H., Wade, M., \& Browne, D. T. (2020). Risk and resilience in family well-being during the COVID-19 pandemic. American Psychologist, 75(5), 631-643. https://doi.org/10.1037/amp00 00660

Russo, D., Hanel, P. H. P., \& Altnickel, S. (2021). Predictors of wellbeing and productivity among software professionals during the COVID-19 pandemic - a longitudinal study. Empirical Software Engineering, 26, 1-62. https://doi.org/10.1007/ s10664-021-09945-9

Sagara, H., \& Das, K. (2020). Technological Disruptions \& the Indian IT Industry: Employment Concerns \& Beyond. In D. Maiti, F. Castellacci, A. Melchior, Digitalisation \& Development: Issues for India \& Development (pp.119-143), Springer.

Schwartz, S.H. (1977). Normative influence on altruism. In L. Berkowitz (ed. pp, 221-279), Advances in Experimental Social Psychology, New York: Academic Press.
Seligman, M. E. P. (2002). Authentic happiness: Using the new positive psychology to realize your potential for lasting fulfilment. Free Press.

Selig, J. P., \& Preacher, K. J. (2009). Mediation models for longitudinal data in developmental research. Research in Human Development, 6(2-3), 144-164. https://doi.org/10.1080/1542760090 2911247

Sharma, R. (2012). Measuring social and emotional intelligence competencies in the Indian context. Cross Cultural Management: An International Journal, 19(1), 30-47. https://doi.org/10.1108/ 13527601211195619

Siangchokyoo, N., Klinger, R. L., \& Campion, E. D. (2020). Follower transformation as the linchpin of transformational leadership theory: A systematic review and future research agenda. The Leadership Quarterly, 31(1), 101341. https://doi.org/10.1016/j. leaqua.2019.101341

Sihag, P. (2020). The mediating role of perceived organizational support on psychological capital-employee engagement relationship: a study of Indian IT industry. Journal of Indian Business Research, Advance online publication. https://doi.org/10.1108/ JIBR-01-2019-0014

Stajkovic, A. D., \& Luthans, F. (1998). Self-efficacy and work-related performance: A meta-analysis. Psychological Bulletin, 124(2), 240-261. https://doi.org/10.1037/0033-2909.124.2.240

Stewart, J., \& McDermott, C. (2004). Gender in psychology. Annual Review of Psychology., 55, 519-544. https://doi.org/10.1146/ annurev.psych.55.090902.141537

Stoker, J. I., Garretsen, H., \& Soudis, D. (2019). Tightening the leash after a threat: A multi-level event study on leadership behavior following the financial crisis. The Leadership Quarterly, 30(2), 199-214. https://doi.org/10.1016/j.leaqua.2018.08.004

Squires, M. A. E., Tourangeau, A. N. N., Laschinger, H. K. S., \& Doran, D. (2010). The link between leadership \& safety outcomes in hospitals. Journal of Nursing Management, 18(8), 914-925. https://doi.org/10.1111/j.1365-2834.2010.01181.x

van Esch, C., Luse, W., \& Bonner, R.L. (2021). The impact of COVID19 pandemic concerns and gender on mentor seeking behavior and self-efficacy. Equality, Diversity and Inclusion. Advance online publication. doi: 10.1108/EDI-09-2020-0279

Wagner, J., Warren, S., Cummings, G. G., Smith, D. L., \& Olson, J. K. (2013). Resonant leadership, workplace empowerment, \& "spirit at work": Impact on registered nurse job satisfaction \& organizational commitment. Canadian Journal of Nursing Research, 45(4), 108-128. https://doi.org/10.1177/084456211304500409

Walumbwa, F. O., Peterson, S. J., Aio, B. J., \& Hartnell, C. A. (2010). An investigation of the relationships among leader \& follower psychological capital, service climate and job performance. Personnel Psychology, 63(4), 937-963. https://doi.org/10.1111/j. 1744-6570.2010.01193.x

Wang, Z., Sun, J. M., \& Zhao, Y. J. (2012). Leadership effectiveness in the Chinese context: a meta-analysis of transformational leadership, leader-member exchange and abusive supervision. Advances in Psychological Science, 20(2), 174-190. https://doi. org/10.3724/SP.J.1042.2012.00174

Wilson, M., \& Liu, J. (2003). Social dominance orientation and gender: The moderating role of gender identity. The British journal of social psychology, 42, 187-198. https://doi.org/10.1348/01446 6603322127175

Wisecup, A., Mcpherson, M., \& Smith-Lovin, L. (2005). Recognition of Gender Identity and Task Performance. Advances in Group Processes, 22(10), 177-201. https://doi.org/10.1016/S08826145(05)22007-6

Wong, C. A., Cummings, G. G., \& Ducharme, L. (2013). The relationship between nursing leadership \& patient outcomes: a 
systematic review update. Journal of Nursing Management, 21(5), 709-724. https://doi.org/10.1111/jonm.12116

Zhang, J., Xie, C., Wang, J., Morrison, A. M., \& Coca-Stefaniak, J. A. (2020). Responding to a major global crisis: the effects of hotel safety leadership on employee safety behavior during COVID-19. International Journal of Contemporary Hospitality Management, 32(11), 3365-3389. https://doi.org/10.1108/ IJCHM-04-2020-0335
Zhao, F., Ahmed, F., \& Faraz, N. A. (2020). Caring for the caregiver during COVID-19 outbreak: Does inclusive leadership improve psychological safety and curb psychological distress? A crosssectional study. International Journal of Nursing Studies, 110, 1-11. https://doi.org/10.1016/j.ijnurstu.2020.103725

Publisher's Note Springer Nature remains neutral with regard to jurisdictional claims in published maps and institutional affiliations. 